\title{
REPRODUCTIVE CYCLE AND MARICULTURE POTENTIAL OF THE RABBITFISH SIGANUS CANALICULATUS IN SAUDI ARABIA
}

\author{
Adel A. Thanvat \\ Department of Animal Production. Faculty of Agriculture. Cairo \\ University. Giza. Egypt.
}

Keywords: Rabbitfish. Siganus canaliculctus, reproduction. fisheries. Arabian Gulf.

\section{ABSTRACT}

$\mathrm{T}$ he present work was meant to the reproductive cycle of the rabbittish Siganus canaliculatus, one of the economically important marine fish inhabiting the Arabian Gulf of Saudi Arabia coast. The future expectations of development of Siganus mariculture were described. This study revealed the sex ratio. gonads maturity stages. size at first sexual maturity, spawning season. ova-diameter and fecundity. The length at first sexual maturity (Lm50) was found to be $18 \mathrm{~cm}$ and $19 \mathrm{~cm}$ for males and females, respectively. Fishes larger than $22 \mathrm{~cm}$ total length of both sexes were found to be fully mature. Although, the gonado-somatic index (GSI) of Siganus canaliculatus differed significantly $(P>0.05)$ between males and females, it exhibited the same trend for both, where GSI reached its maximum values (peaks) of 18.0 and 22.5 during May for males and females, respectively. The spawning season was found to be short and occurred during the period from April to June, with a high peak during May, which means that one spawning season was exhibited. The egg-diameter distribution was significantly variable in the ripe ovaries with largest egg diameters ranging from 0.3 to $0.4 \mathrm{~mm}$, which constitute about $88 \%$ of the total eggs and revealing one peak during May. Absolute fecundity was increased with increasing length. weight and age of the fish. Fecundity exhibited a curvilinear trend or exponential equation with fish length, fish weight and fish age. The mean sex ratio (Males: Females) for the whole year was 1:1.13. It was recommended that capturing of fish smaller than $20 \mathrm{~cm}$ total length should be prohibited to protect the spawning stock biomass of rabbitfish $S$. canaliculatus on the long run. Also, many aspects for mariculture potential were included. 


\section{INTRODUCTION}

The White Spotted Rabbitfish Siganus canaliculatus (Park. 1797). has a local name 'Safi' in the western coast of Arabian Gulf, as it has been popular with excellent marketing and a good price. Moreover, it is relatively easy to rear and thus considered suitable for aquaculture (Lam, 1974; Bryan \& Madraisau, 1977; Juario et al., 1985 ; Hara et al., 1986 a \& b). There have been attempts to breed and rear two Siganus species in the Arabian Peninsula; the marbled spinefoot Siganus rivulatus Forsk (Al Thobaity el al., 1984) and the pearl (white) spotted Siganus canaliculatus Park (Al-Ghais, 1993). Few studies are available on some biological aspects of $S$. canalculatus in the Arabian Gulf. which did not cover the life history. So, the present work aimed to investigate the reproductive cycle of this fish including gonad developmental stages, adult sex ratio, gonado-somatic index. timing of spawning season. size and age at first sexual maturity, egg diameters and fecundity. The mariculture potential of $S$. canaliculatus in the Arabian Peninsula was discussed with the available biological information in the literature. which will help to develop fish production in Arabian Gulf on a scientific basis.

\section{MATERIALS AND METHODS}

Specimens of Rabbitfish Siganus canaliculatus were collected monthly during the period from January 2002 to December 2002 by professional fishermen using trammel gillnets at Al-Qatif and AlJubil coasts of Saudi Arabia on the Arabian Gulf. Fishes were put immediately in crushed ice and transported to the laboratory. where they were measured and investigated. Date of capture. fish total length (mm) and fish total weight $(0.1 \mathrm{~g})$ were recorded for each fresh specimen. Fishes were dissected to define their sex. gonads maturity stage and fullness of alimentary canal. Fresh gonads were removed and visually inspected for size. colour. vascularization and presence of milt and oocy'tes. Maturity stages for Siganids species according to AI-Ghais. (1993) and El-Sayed \& Bary. (1994) were adopted for the present study. Gutted fish were weighed to the nearest $0.1 \mathrm{~g}$ and gonads were weighed to the nearest $0.001 \mathrm{~g}$. then the ripe ovaries were fixed immediately in $5 \%$ buffered formaldehyde for fecundity and ova diameter investigation. Fish were identified as either immature (with at stage 1 or 2. being small and undeveloped) or mature (with 
enlarged gonads. and in case of females. recruiting vitellogenic oocytes were present). For both males and females. frequency data of status of maturity were assembled on length and body weight. The length at which $50 \%$ of fishes reach their sexual maturity was considered as the length at first sexual maturity "Lm L $_{50}$ "(Pitt. 1970) and was derived from the length frequency distribution of mature males and females. The gonado-somatic index (G.S.I.) was calculated for each specimen using the following equation:

GSI 100 [gonads weight (g)/gutted weight (g)], the spawning season was determined by curvilinear of the average monthly GSI for both males and females. Ripening pair of ovaries were fixed in $5 \%$ formaldehyde in glass tubes. with labels indicating date of capture. fish-length. fish weight and gonad weight in order to estimate fecundity. From each three subsamples, each approximately $3 \%$ of gonad weight. were removed and weighed to the nearest $0.001 \mathrm{~g}$ and the eggs were counted in a Petri dish under a dissecting microscope at a power of $20 \mathrm{X}$. The absolute fecundity was calculated as the average number of eggs contained in the ovary per individual fish. The numbers of eggs in the three subsamples were averaged $(n)$, and then the total number of eggs in the two ovaries (N) was estimated as follow: $\mathrm{N}=\mathrm{n} \times$ [weight of ovaries / weight of sample]. Fish age was based on an age-length key according to Tharwat (2004). Egg diameters were measured monthly using; a research microscope aided with an ocular micrometer at a power of $100 \mathrm{X}$. Simple regression, standard deviation of mean values for the relationships between estimated fecundity and fish length, fish weight and fish age were computed and the differences between males and females were tested by analysis of variance, according to Schaffer and Elson, (1975) using the program of SAS, (1990).

\section{RESULTS AND DISCUSSION}

\section{Maturity: stages}

A macroscopic description of the gonads maturity stages for males and females of Siganus canaliculatus are given in Table (1). Macroscopic criteria such as gonad size, shape, texture and color were used to classify the gonad maturity stages in the fish. The main criteria were adopted by many authors (Munro et al., 1973. Hasse et al., 1977, Chan and Chua, 1980, Hara et al., 1986a ; AL-Ghais, 1993). It was found that $S$. canaliculatus have unequal gonad lobes. 
where the left lobe of ovary or testis becomes bigger in size throughout maturation cycle than the right lobe when developed. The left lobe is relatively flat and covers the entire left surface of the cavity. The right one is more rounded and elongated, pushing the gut upward. At the same maturity stage, ovaries and testes were relatively similar in appearance and size for $S$. canaliculatus. Undeveloped or juvenile gonads (stage I) were small, cylindrical and occupied a minute portion of the lower body cavity, located over the posterior part of the pelvic fins, and extending posteriority. In April and May all maturity stages were found, thus the spawning season of $S$. canaliculatus extends from April to June with a peak in May. In general, the gonads development of Siganus species is affected by several environmental conditions such as: 1) temperature, where the rapid gonadal development usually occurs when the water temperature ranged from $25-30^{\circ} \mathrm{C} ; 2$ ) Junar cycle, where gonads of $S$. canaliculatus mature during new moon; 3) photoperiod (e.g. $18 \mathrm{~h}$ light : 6 h dark retards gonadal maturation of $S$. cancliculatus) (Lam and Soh, 1975); and 4) quantity and quality of diet (e.g. females of $S$. guttatus fed with commercial diet containing $43 \%$ protein spawned monthly for 11 months; when lecithin. cod liver oil, or both were added to the diet. spawning occurred for at least 4 consecutive months) (Hara et al.. 1986a).

\section{Sex ratio}

The length frequency distribution, percentage of males and females of $S$. canaliculatus and the sex ratio with length intervals are shown in Table (2). It was obvious that sex-ratio deviate significantly from 1:1 among the size classes. However. The overall sex ratio (Males: Females) of this species during the year was $1: 1.13$ and did not differ significantly from 1:1. The present result agrees with others on the same species in Qatar that was found to be 1:1.09 for males: females (El-Sayed and Bary. 1994) and slightly differ from that of 1.1:1.0 (Wassef and Abdul Hady, 1997) on the same species in Saudi Arabia. On the other hand, there was a predominance of males amongst the smallest size ranging from 14 to $22 \mathrm{~cm}$ total length. while females were predominated for the size larger than $22 \mathrm{~cm}$ (Table 2). Similar results indicated that female $S$. rivulams significantly dominated catches along the Syrian coast (Saad \& Sabour. 2001). Hashem (1983) indicated a slight dominance of female $S$. rivilanus (1:13) in Red Sea populations but it is unclear whether this ratio was significantly different from $1: 1$. 


\section{Gonadosomatic Index}

Among the widely accepted measures of sexual activity in tishes is the Gonadosomatic index (GSI), which is an indicator commonly used for depicting annual reproductive cycles in fishes (Crim \& Glebe. 1990). The monthly variations of the mean GSI of Siganus canaliculatus for males and females were graphically represented in Figure (1). It is obvious that G.S.I. values were relatively higher for females than males. The GSI of Siganus canaliculatus nearly exhibited the same trend for two sexes, where its average values increased during the period from March to June then sharply decreased during July and returns to dormancy from August to Febraury. The GSI reached its maximum values (peaks) of 18.0 and 22.5 during May for both males and females. respectively. This result indicated that the rabbitfish $S$. canaliculatts in the western coast of Arabian Gulf of Saudi Arabia spawns once a year. and the spawning season extends from April to June. The reproductive cycle and gonad maturation in fishes also differs during the different months of the year. According to this scale, ripe and spawning fishes were abundant in the present study during April through June. Thus, the present results confirmed that the spawning season of $S$. canaliculatus extends through these months of the year and the peak of sexual activity occurs in May. Similar results were ubtained on the same species in Qatar (El-Sayed and Bary. 1994) and in Saudi Arabia during April and May when average temperature varied between 22.5 and $25^{\circ} \mathrm{C}$ (Wassef and Abdul Hady, 1997) However, Al-Ghais.(1993) indicated that GSI of $S$. canaliculatus in the Southern coast of Arabian Gulf in U.A.E. begins to rise in February to a maximum in April, when full ripeness was attained for most fishes. The relatively early spawning in U.A.E. may be attributed to the higher water temperature. A similar trend was also noticed for $S$. rivulatus and $S$. luridus in the Mediterranean Sea, where their spawning occurred in June, when surface water temperature ranged between 24 and $29^{\circ} \mathrm{C}$ (Bariche et al., 2003). Although differences in spawning intensity and duration may vary between years, defining a spawning season for a species should be based on a large number of specimens sampled regularly over a relatively long period and be coupled with physical and chemical factors (e.g. water temperature, salinity and luminosity). Previous studies on the reproductive biology of siganid species have shown that water temperature plays a role in the determination of the timing and duration of spawning season (Lam \& Soh, 1975; Popper el 
al.,1976; Amin,1985a. b). In Jeddah, Amin (1985a, b) reported that $S$. rivulatus spawned from March to September. However. in the Mediterranean Sea, a spawning season is restricted to June for $S$. rivulatus as reported by Popper \& Gundermann (1975) and Bariche et al. (2003)

\section{Fish size at onset of sexual maturity}

The progression of the percentage of mature males and females of the rabbitfish $S$. canaliculatus for the total lengths ranging from $15-34$ and $15-36 \mathrm{~cm}$ respectively is represented in Figure (2). The estimated mean length at first sexual maturity (Lm50) of $S$. canaliculatus was found to be 18 and $19 \mathrm{~cm}$ for males and females, respectively. Specimens larger than $22 \mathrm{~cm}$ in total length were found to be fully mature for both sexes. The calculated ages at the onset of sexual maturity ( $\mathrm{tm} 50$ ) by applying age determination formula of Tharwat (2004) were 1.27 and 1.36 years for males and females, respectively. These results support those of Hasse et al. (1977) on $S$. canalicularus in Palau. They concluded that the fish reaches sexual maturity within the first year of their life span. Spawning occurred from April to June where high temperature in summer appeared to be a limiting factor for the gonad development, reducing the breeding season. Maturity stages of gonads can be successfully applied in the field for getting an approximate jdea about the spawning season and its duration. Investigation of the maturity stages of the ovaries and testes for each specimen of $S$. canaliculatus during all months of the year revealed that males attained their first sexual maturity slightly earlier than females. In comparing the size at first sexual maturity $(\operatorname{Lm} 50)$ of the present $S$. canaliculatus with previous studies. there seems a good agreement. However. El-Sayed and Bary (1994) found that $\mathrm{Lm} 50$ was about $17.7 \mathrm{~cm}$ for males and $17.2 \mathrm{~cm}$ for females ai Qatar coasts. Wassef and Abdul Hady. (1997) reported that Lm50 corresponds 1017 and $18 \mathrm{~cm}$ in Arabian Gulf at Saudi Arabia coast for males and females. respectively. From the present study it can be recommended that capturing fish smaller than $20 \mathrm{~cm}$ total length should be prohibited in order to protect the spawning stock biomass on the long run.

\section{Egg diameter}

When Siganus fish reaches maturity. the eggs appear small. spherical. demersal and strongly adhesive (Subandiyono el al.. 2000). except in case of $S$. argentens that are free-floating and non-adhesive 
(Lam. 1974). This sticky layer enables the eggs to attach to any type of substrate. whether floating or static. as spawning sites. The eggdiameter frequency distribution in the ripe ovaries of prespawning females of the rabbitfish $S$. cunaliculatus and the monthly variation of the egg-diameter are graphically represented in Figures ( 3 and 4 ). respectively. The variation of egg diameter distribution within ripe ovaries, suggests a rather short spawning season, in which eggs were released in batches. The ripe eggs ranging from $0.30-0.40 \mathrm{~mm}$ and the smaller eggs ranging from $0.10-0.25$ both constitute about $88 \%$ and $12 \%$ from the total eggs in the ripe ovaries, respectively (Fig. 3 ). On the other hand, the mean egg-diameters were 0.12 and $0.17 \mathrm{~mm}$ in January and February. respectively, then an abrupt increase was observed during the period from March - May to reach its maximum value of $0.40 \mathrm{~mm}$ in May. A gradual decrease took place afterwards during the successive months from June to August, with a mean of $0.21 \mathrm{~mm}$, followed by a sharp decrease to reach its minimum value $(0.10 \mathrm{~mm})$ in December (Fig. 4$)$. It is obvious that the monthly eggdiameter distribution of $S$. canaliculatus followed nearly a similar pattern to GSI, while the oocytes attain their maximum developmental size just before or during the breeding season (Shenouda, 1988). Therefore, the present result confirms that $S$. canaliculatus has one definite spawning season. which occurs during the period from April to June throughout the year. Estimation of the mean egg diameter in different months gives an idea about the maximum size of eggs and duration of the spawning season, whether short or long. It also shows one peak during May, confirming the previously deduced results, from the GSI values.

\section{Fecundity}

Two terms are usually applied in fecundity studies; namely the absolute and relative fecundity where the former denotes the total number of ripe eggs in the ovary, whereas the relative fecundity denotes the number of these eggs per unit length, weight or age of fish.

\section{Relationship between fecundity and fish length}

The relationship of the absolute and relative fecundity with the total length of Siganus canaliculatus is shown in Table (3). In general, absolute fecundity was higher in larger fish. Female ranging in total length from 17 to $35 \mathrm{~cm}$ produces 58925 to 838652 eggs. The 
relationship can be represented by the following exponential equation: $F=1.910 \mathrm{~L}^{3.6540}, \mathrm{r}=0.979$, where $F$ is the absolute fecundity, $L$ is the total length of fish $(\mathrm{cm}), r$ is the correlation coefficient of the regression. The relative fecundity increased regularly from 3466 to $23961 \mathrm{eggs} / \mathrm{cm}$ with a mean of 5645 eggs per $\mathrm{cm}$ length increment. In comparing the present results with those of some authors on $S$. canaliculaizs in different Arabian Gulf countries, it was found that the absolute fecundity ranged between 650,000 and $1,000,000$ eggs per female in U.A.E. (AL-Ghais, 1993), between 225700 and 1,050,000 eggs in Qatar (El-Sayed and Bary, 1994) and from 42253 to more than one milion for fish between $17-41 \mathrm{~cm}$ total length in Saudi Arabia (Wassef and Abdul Hady, 1997). The relative variation of fecundity could be attributed to the fish size and localities, which is directly affected by fishing pressure among the successive years.

\section{Relationship between fecundity and fish weight}

Table (4) shows the relation of absolute and relative fecundity with fish-weight. The results revealed that the absolute fecundity increased with increasing weight of the fish, which increased from 62420 to 983517 eggs for different weight groups that ranged between 75 to $575 \mathrm{gm}$. The relation between these two variables could be expressed by the following exponential equation: $F=180.12$ $W^{1.3542}, r=0.9985$. where $F$ is the absolute fecundity, $W$ is fish weight $(g) . r$ is the correlation coefficient of the regression. So a high agreement between the mean observed and calculated fecundity for different weight groups (Table 3). On the other hand, the relative fecundity-weight values slightly increased with iweight increment, ranging between $832-1710$ eggs / $g$ with the mean of 1352 eggs per gram.

\section{Relationship between fecundity and fish age}

The average numbers of eggs for the successive age groups of Siganus canaliculatus are shown in Table (5). It was found that the number of eggs greatly varied within any' age group. This variation is greater than that between fishes of the same length or weight groups. The relationship belween absolute fecundity $(F)$ and fish age can be expressed by the following exponential equation: $F=55267 \mathrm{G}^{1.7} \cdot \mathrm{r}=$ 0.9795 . where $G$ is the fish age by year, $r$ is the correlation coefficient of the regression. Generally. the mean number of eggs increased. as the fisli got older. Thus. it increased from 55173 eggs in fishes of age 
group $\llbracket$ to 852376 eggs in fishes of age-group $V$. This indicates that Siganus canaliculatus did not reach the senility age and still possesses an economic importance. However the relative fecundity (eggs/year) in the successive age groups was increasing with older fish (Table. 5). The increase in age is usually accompanied by increase in length and weight. so fecundity increases as well. This increase continues until the senility age, at which it stops increasing. The commercial fish species, which has an economic importance. does not reach this age (Nikolsky.1963). Generally. the present results indicate that $S$. cancliculatus is a highly fecund species and the relation between fecundity and length or weight of a fish may exhibit a nonlinear trend. These results are comparable with those of earlier workers on Siganids (Lam. 1974; Alcala and Alcazar. 1979: Woodland, 1979; Tseng and Chan, 1982; Al-Ghais, 1993; El-Sayed and Bary, 1994 ; Wassef and Abdul Hady, 1997).

\section{Prospective potential of rabbitfish mariculture in Saudi Arabia}

$A \dot{s}$ the biological aspects and feeding habits of rabbitfish vary between species, special attention to one or few commercial species that have potential for mariculture is needed. Considerations include the ease of spawning, with or without hormonal treatment. The chosen species should be fecund. fast growing and suited to intensive culture. Based on the above mentioned. findings it can be suggested that $S$. canaliculatus is an important species for mariculture in the Arabian Gulf. This fish has potential prospects to be cultured commercially in some countries i.e. Saudi Arabia, Bahrain, Kuwait. United Arab Emirates and Indonesia as they are suited to the local growing conditions and have a recognized delicacy with a moderate market value (Duray, 1990). Other factors which encourage farming of rabbitfish in Saudi Arabia and Arabian Gulf countries are: 1) It is an excellent food with high market value in many countries. 2). The juveniles and adult fish mostly occupy shallow water (Lam, 1974; Popper et al., 1979). Therefore, the fish can be grown using a simple floating cage in the commercial farming, and don't require a deep cage. 3) They inhabit different types of habitat (e.g. coral reef, sandy and rocky bottom (with or without vegetation). lagoons, river estuaries, and mangrove swamps) (Lam, 1974; Popper and Gundermann, 1975; Woodland and Randall, 1979). 4) Sites suited to this type of fish farm are easy to find in the Arabian Gulf. 5) Rabbitfish are able to take an artificial diet (Bwathondi, 1982; Juario 
et al., 1985; Hara et al., 1986a; Subandiyono, 1999). 6) Many types of commercial diet for fish have been produced by a large quantity, which encourages mass production, using intensive culture system. 7) The fish can be cultured in monoculture or polyculture system with milkfish (Chanos chanos), mullets (Mugil and Liza spp.) or seabream fishes (Lichatowich and Popper, 1975; Bagarinao, 1986), without affecting growth. 8) Rabbitfish can be used to control the growth of filamentous algae if they are stocked in shrimp ponds and tropical oyster or clam culture (Chen, 1990). 9) The fish spawns easily, whether naturally or by using hormonal treatment (Ayson and Lam, 1993; Subandiyono et al., 1999 \& 2000). 10) The fecundity is relatively high, approximately 0.8 million eggs for $400 \mathrm{~g}$ fish and 1.2 million for $520 \mathrm{~g}$ fish (Popper and Gundermann, 1976). 11) Though the larvae are very fragile, they can be transported for 2 days using simple equipment (Basyari el al., 1988). 12) Large numbers of rabbitfish juveniles can be collected from coastal waters during certain seasons (Lam. 1974). 13) Labor cost is relatively cheaper. 14) They can be used as a bait to catch tuna (Duray, 1990). On the other hand. there are some undesirable characteristics that included: 1) The larvae have a relatively small mouth gape at the first opening. i.e. about $125 \mu \mathrm{m}$ (Duray and Kohno. 1988). Therefore. they need small size feeds. 2) The fish are difficult to handle due to the poisonous spines that may induce severe headaches (Herzberg, 1973). 3) The sex is difficult to distinguish except during the breeding season (Duray, 1990). 4) It is difficult to differentiate between the species due to only few morphological differences. Therefore; the identification relies only on the coloration of live fish, habitat. and behavioral characteristics (Woodland and Randall. 1979). In general. rabbitfish culture has a tremendous potential in Saudi Arabia and other Arabian countries.

\section{REFERENCES}

Alcala. A. C. and Alcazar. S. N. (1979). A study on gonad morphology: oocye development. gonad index and fecundity in the rabbitfish Siganus canaliculatus (Park). Silliman J.. 26 (2-3): 147-162.

Al-Ghais. S. M. (1993). Some aspects of the biology of Sigamus canalicularus in the southern Arabian Gulf. Bull. Mar. Sci.. 52(3): 886-897. 
Al Thobaity, S. ; Bokhary, F. and Badawi, A. (1984). Cultivation of siganids in the Red Sea. Report Min. Agric. Water Res. Jeddah, Saudi Arabia, 71 pp. (in Arabic).

Amin. E. M. (1985a). Seasonal developmental changes in the ovaries of Siganus rivulatus from the Red Sea. Bull. Inst. Oceanogr.\& Fish. (A.R.E.) 11:131-147.

Amin, E. M. (1985b). Reproductive cycle of male Siganus rivulatus Forsk. with indication to gonadosomatic and hepatosomatic indices. Bull. Inst. Oceanogr. \& Fish. (ARE) $\overline{11}$ : 149-164.

Ayson, F. G. and Lam, T. J. (1993). Thyroxine injection of female rabbitfish Siganus guttatus broodstock: changes in thyroid hormone levels in plasma, eggs and yolk-sac larvae and its effect on larval growth and survival. Aquacult., 109: 83-93.

Bagarinao, T. (1986). Yolk resorption, onset of feeding and survival potential of larvae of three tropical marine fish species reared in the hatchery. Mar. Biol., 91: 449-459.

Bariche, M. ; Harmelin, M. V. and Quignard, J. P. (2003). Reproductive cycle and spawning periods of two Lessepsian siganid fishes on the Lebanese coast. J. Fish Biol.. 62: 129142.

Basyari. A. ; Danakusumah. E. : Philip, T. I. ; Pramu, S. and Musthahal dan Isra. M. (1988). Budidaya ikan beronang (Siganus sp.). INFIS. No. 60, Direktorat Jenderal Perikanan. 31 hal.

Bryan. P. G. and Madraisau. B. B. (1977). Larval rearing and development of Siganus lineatus (Pisces. Siganidae) from hatching through metamorphosis. Aquacult.. $10(3)$ : 243-252.

Bwathondi. P. O. J. (1982). Preliminary investigations on rabbitfish. Siganus canaliculatus. cultivations in Tanzania. Aquacult.. $27(2): 205-210$. 
Chan. E. H. and Chua, T. E. (1980). Reproduction in the greenback grey mullet, Liza subviridis (Valenciennes. 1836). J. Fish Biol. 16: 505-510.

Chen. L. C. (1990). Aquaculture in Taiwan. Fishing News Books. Oxford. USA. 273pp.

Crim. L. W. and Glebe. B. D. (1990). Reproduction. In Methods for Fish Biology (Schreck. C. B. and Moyle. P. B.. eds). pp. 529-553. Bethesda. MD: American Fisheries Society.

Duray, M. N. (1990). Biology and culture óf siganids. Aquaculture Department, SEAFDEC, Philippines. 47 pp.

Duray, M. and Kohno. H. (1988). Effects of continuous lighting on growth and survival of first-feeding larval rabbitfish, Siganus guttatus. Aquacult., 72: 73-79.

El Sayed, A. M. and Bary, K. A. (1994). Life cycle and fecundity of rabbitfish Siganus canaliculatus (Teleostei : Siganidae) in the Arabian Gulf. Oebalia, 20: 79-88.

Hara, S. ; Duray, M. ; Parazo, M. and Taki, Y. (1986a). Year-round spawning and seed production of the rabbitfish, Siganus guttatus. Aquacult., 59: 259-272.

Hara, S. ; Kohno, H. and Taki, Y. (1986b). Spawning behavior and early life history of Siganus guttatus in the laboratory. Aquacult., 59: 273-285.

Hashem, M. $\vec{T}$. (1983). Biological studies on Siganus rivulatus (Forssk.) in the Red Sea. J. Fac. Mar. Sci., 3: 119-127.

Hasse, J. J. ; Madraisau, B. B. and McVey J. P. (1977). Some aspects of the life history of Siganus canaliculatus Park (Pisces: Siganidae) in Palau. Micronesica, 13: 297-312.

Herzberg, A. (1973). Toxicity of Siganus luridus (Ruppell) on the Mediterranean coast of Israel. Aquacult. 47: 53-59. 
Juario, J. V. : Duray. M. N. : Duray, V. M. ; Nacario, J. F. and Almendras. J. M. E. (1985). Breeding and larval rearing of the rabbitfish Siganus guttatus (Bloch). Aquacult., 44:91101.

Lam, T. J. (1974). Siganids: their biology and mariculture potential. Aquacult., 3: 325-354.

Lam, T. J. and Soh, C. L. (1975). Effect of photoperiod on gonadal maturation in the rabbitfish Siganus cunaliculatus (Park,1797). Aquacult.. 5: 407-410.

Lichatowich, T. and Popper, D. (1975). Report on the growth of rabbitfish in fish ponds in Fiji. Aquacult., 5: 211-212.

Munro, J. L. ; Gaut. V. C. ; Thompson, R. and Reeson, P.H. (1973). The spawning season of Caribbean ref fishes. J. Fish Biol., 5: 69-84.

Nikolsky, G. V. (1963). The ecology of fishes. Academic Press. London and New York.

Pitt, T. K. (1970). Distribution. abundance and spawning of yellow tail flounder Limanda ferruginea in the new foundland area, the North-West Atlantic. J. Fish. Res. Board, Canada. 27 (12): $2261-2271$.

Popper. D. and Gundermann. N. (1975). Some ecological and behavioral aspects of siganid populations in the Red Sea and Mediterranean coast of Israel in relation to their suitability for aquaculture. Aquacult.. 6: 127-141.

Popper. D. and. Gundermann. N. (1976). A successful spawning and hatching of Siganus vermiculatus under field conditions. Aquacult. i: 291-292.

Popper. D. : May. R. C. and Lichatowich. T. (1976). An experiment in rearing larial Siganus vermicularus (Valenciennes) and some observations on its spawning cycle. Aquacult.. 7: 281290. 
Popper. D. H. : Pitt. R. and Zohar. Y. (1979). Experiments on the propagation of Red Sea siganids and some notes on their reproduction in nature. Aquacult.. 16:177-181.

Saad. A. and Sabour, W. (2001). Donnees preliminaires sur la reproduction de Siganus rivlulatus (Forskal. 1777). Pisces. Siganidae), dans les eaux cotieres de Syrie. Rapport du 36 Congres de la Commission Internationale Pour l'Exploration Scientifique de la Mer Mediterranee $36: 319$.

SAS, (1990). Statistical analytical systemș user's guide (Vol. 2). Carg, NC : SAS Institute Inc. USA.

Schaffer, W. M. and Elson, F. P. (1975). The adaptive significance of variations in life history among local populations of Atlantic salmon in North America. Ecology, 56: 577-590.

Shenouda, T. S. (1988). Spawning peculiarities of Trachurus trachurus L. (Fam. Carangidae) in the Mediterranean Sea. Delta J. Sci., 12(4): $1711-1723$. ?."

Subandiyono, (1999). Growth of rabbitfish, Siganus sp., in captivity fed by diets containing different level of soy-lecithin. Journal of Coastal Development, 2(3): 419-425.

Subandiyono, Kokarkin, C. and Dan Hastuti, S. (1999). Paket teknologi formulasi pakan induk ikan beronang (Siganus sp.) guna meningkatkan kualitas telur. Tahun II. LemlitUniversitas Diponegoro, 81 hal.

Subandiypno, Kokarkin, C. and Dan Hastuti, S. (2000). Paket teknologi formulasi pakan induk ikan beronang (Siganus sp.) guna meningkatkan kualitas telur. Tahun III. LemlitUniversitas Diponegoro. 102 hal.

Tharwat, A. A. (2004). Population dynamics of the rabbitfish Siganus canaliculatus from the Arabian Gulf of Saudi Arabia. Egypt. J. Aquat. Biol. \& Fish., (in publication). 
Tseng. W. Y. and Chan, K. L. (1982). The reproductive biology of the rabbitfish in Hong Kong. J. World Maricult. Soc.. 13: 313-321.

Wassef, E. A. and Abdul Hady, H. A. (1997). Breeding biology of rabbitfish Siganus canaliculatus Park in mid Arabia Gulf. Fish. Res., Amsterdam. 33: 159-166.

Woodland. D. J. (1979). Rabbitfishes neglected in Australia are important food fish in tropical countries. Aust. Fish., $38(6)$ : 21-23.

Woodland, D. J. and Randall, J. E. (1979). Siganus puelloides, a new species of rabbitfish from the Indian Ocean. Copeia, 3: 390393. 
Table (1). The maturity stages of Siganus canaliculatus inhabiting the Arabian Gulf.

\begin{tabular}{|c|c|}
\hline $\begin{array}{l}\text { Maturity stage } \\
\text { (Classification }\end{array}$ & Description \\
\hline $\begin{array}{c}0 \\
\text { (Immature) }\end{array}$ & $\begin{array}{l}\text { No easily visible gonads in body cavity. Sex cannot be determined } \\
\text { macroscopically }\end{array}$ \\
\hline $\begin{array}{c}\text { I } \\
\text { (Maturing) }\end{array}$ & $\begin{array}{l}\text { Gonads are represented by two thin tubular units threadlike. } \\
\text { transparent and can be distinguished into testis or ovary. }\end{array}$ \\
\hline $\begin{array}{c}\text { (II } \\
\text { (Early } \\
\text { developed) }\end{array}$ & $\begin{array}{l}\text { Ovaries begin to swell. enlarged, still translucent and easily } \\
\text { recognized. Oocytes cannot visually discernible. Male testes are } \\
\text { enlarged, opaque and easily recognized. }\end{array}$ \\
\hline $\begin{array}{l}\text { (Mid } \\
\text { developed) }\end{array}$ & $\begin{array}{l}\text { Ovaries larger, occupying about } 50 \% \text { of the body cavity, visible } \\
\text { asymmetric and borders are more rounded than testes, with a } \\
\text { circular cross-section. Ovaries pale yellow to dark-pink in color } \\
\text { Vascularization starts to appear and Oocytes can visually } \\
\text { discernible. Testes marked asymmetry with triangular cross- } \\
\text { section. Whitish gray in color and sometimes bluish and } \\
\text { Vascularization is not visible. }\end{array}$ \\
\hline $\begin{array}{l}\text { IV } \\
\text { (Ripe) }\end{array}$ & $\begin{array}{l}\text { Enlarged ovaries, solid and occupying about } 75 \% \text { of the body } \\
\text { cavity, with rounded borders, marked asymmetric and well- } \\
\text { developed vascularization. Colour ranges from pale to darker } \\
\text { yellow. Eggs fully formed, numerous and clearly visible to naked } \\
\text { eye. Testes usually white, cleared asymmetric with triangular } \\
\text { cross-section and some sperms expelled from core when testis is } \\
\text { cut. }\end{array}$ \\
\hline$\underset{(\text { Spawning) }}{\mathrm{V}}$ & $\begin{array}{l}\text { Fisl about to spawn. Gonad turgid and filing the body cavity. } \\
\text { Swollen ovaries with a dark yellow and sometimes orange colour. } \\
\text { Strongly asymmetric and vascularization is well developed. Eggs } \\
\text { are transparent and are expelled with a slight pressure on the } \\
\text { abdomen. Testes are strongly asymmetric and ivory colour. } \\
\text { Vascularization is not clear visible. Characterized by the presence } \\
\text { of milt flowing freely when the abdomen is compressed. }\end{array}$ \\
\hline $\begin{array}{c}\text { VI } \\
\text { (Spent) }\end{array}$ & $\begin{array}{l}\text { Ovaries significantly reduced in volume of the body cavity, flaccid } \\
\text { and slirink but not fully empty. Ovaries reddish yellow in colour } \\
\text { and eggs seen by naked eye. Vascularization relatively well } \\
\text { developed. Spent testes relatively hard to recognize. Sometimes } \\
\text { little sperm flows. Relatively similar to stage III but more flaccid, } \\
\text { dull-gray color, soft, and fleshy in its appearance. }\end{array}$ \\
\hline
\end{tabular}


OF THE S. CANALICULATUS IN SAUDI ARABIA

Table (2). The percentage of males and females of the rabbitfish Siganus canaliculatus in length intervals and the sex ratio (Males: Females).

\begin{tabular}{|c|c|c|c|c|c|c|}
\hline \multirow{2}{*}{$\begin{array}{c}\text { Total length } \\
(\mathbf{c m})\end{array}$} & Freq. & \multicolumn{2}{|c|}{ Males } & \multicolumn{2}{c|}{ Females } & Sex Ratio \\
\cline { 3 - 7 } & & $\begin{array}{c}\text { Numbe } \\
\mathbf{r}\end{array}$ & $\%$ & $\begin{array}{c}\text { Numbe } \\
\mathbf{r}\end{array}$ & $\%$ & $(\mathbf{M}:$ F) \\
\hline $\mathbf{1 4 - 1 6}$ & 68 & 38 & 55.9 & 30 & 44.1 & $1: 0.79$ \\
\hline $16-18$ & 131 & 70 & 53.4 & 61 & 46.6 & $1: 0.87$ \\
\hline $\mathbf{1 8 - 2 0}$ & 234 & 127 & 54.3 & 107 & 45.7 & $1: 0.84$ \\
\hline $20-22$ & 391 & 197 & 50.4 & 194 & 49.6 & $1: 0.98$ \\
\hline $\mathbf{2 2 - 2 4}$ & 304 & 131 & 43.1 & 173 & -56.9 & $1: 1.32$ \\
\hline $24-26$ & 209 & 98 & 46.9 & 111 & 53.1 & $1: 1.13$ \\
\hline $26-28$ & 143 & 64 & 44.8 & 79 & 55.2 & $1: 1.23$ \\
\hline $28-30$ & 86 & 38 & 44.2 & 48 & 55.8 & $1: 1.26$ \\
\hline $30-32$ & 36 & 13 & 36.00 & 23 & 64.0 & $1: 1.77$ \\
\hline $32-34$ & 19 & 3 & 15.8 & 16 & 84.2 & $1: 5.33$ \\
\hline $34-36$ & 4 & - & - & 4 & 100. & - \\
\hline Total & $\mathbf{1 6 2 5}$ & $\mathbf{7 7 9}$ & $\mathbf{4 7 . 9}$ & $\mathbf{8 4 6}$ & $\mathbf{5 2 . 1}$ & $1: 1.13$ \\
\hline
\end{tabular}

Table (3): The relationship between fecundity and the total length (L) of the rabbitfish Siganus canaliculatus collected from the Arabian Gulf in Saudi Arabia.

\begin{tabular}{|c|c|c|c|c|c|}
\hline \multirow{2}{*}{$\begin{array}{l}\text { Total } \\
\text { length } \\
(\mathrm{cm}) .\end{array}$} & \multirow{2}{*}{$\begin{array}{l}\text { Mean } \\
\text { length } \\
(\mathrm{cm})\end{array}$} & \multirow{2}{*}{$\begin{array}{l}\text { No. of } \\
\text { fish }\end{array}$} & \multicolumn{2}{|c|}{ Absolute fecundity } & \multirow{2}{*}{$\begin{array}{c}\text { Relative } \\
\text { fecundity } \\
\text { (Eggs/-cm) }\end{array}$} \\
\hline & & & observed & $\begin{array}{c}\text { calculate } \\
\text { d }\end{array}$ & \\
\hline $16-18$ & 17 & 3 & 58925 & 59854 & 3466 \\
\hline $18-20$ & 19 & 5 & 88979 & 89867 & 4683 \\
\hline $20-22$ & 21 & 4 & 130251 & 129546 & 6202 \\
\hline $22-24$ & 23 & 5 & 181124 & 180629 & 7875 \\
\hline $24-26$ & 25 & 7 & 250076 & 244966 & 10003 \\
\hline $26-28$ & 27 & 6 & 329815 & 324516 & 12215 \\
\hline $28-30$ & 29 & 8 & 421630 & 421343 & 14539 \\
\hline $30-32$ & 31 & 6 & 537871 & 537612 & 17351 \\
\hline $32-34$ & 33 & 4 & 680253 & 675590 & 20614 \\
\hline $34-36$ & 35 & 3 & 838652 & 837641 & 23961 \\
\hline Total & - & 51 & - & - & - \\
\hline Mean & 26 & 5.1 & 214275 & 214312 & 5645 \\
\hline
\end{tabular}


Table (4): The relationship between fecundity and the total weight (W) of the rabbitfishSigunus: canaliculatus collected from the Arabian Gulf in Saudi Arabia.

\begin{tabular}{|c|c|c|c|c|c|}
\hline $\begin{array}{c}\text { Total } \\
\text { weight } \\
(\mathbf{g})\end{array}$ & $\begin{array}{c}\text { Mean } \\
\text { weigh }\end{array}$ & $\begin{array}{c}\text { No. of } \\
\text { (g) }\end{array}$ & \multicolumn{2}{|c|}{ Absh } & \multicolumn{2}{|c|}{$\begin{array}{c}\text { Relative } \\
\text { fecundity } \\
\text { (Eggs /g) }\end{array}$} \\
\hline $50-100$ & 75 & 3 & 62420 & 62340 & 832 \\
\hline $100-150$ & 125 & 5 & 124279 & 124508 & 992 \\
\hline $150-200$ & 175 & 4 & 196573 & 196374 & 1123 \\
\hline $200-250$ & 225 & 5 & 275967 & 275986 & 1227 \\
\hline $250-300$ & 275 & 7 & 362354 & 362165 & 1318 \\
\hline $300-350$ & 325 & 6 & 455201 & 454103 & $140 !$ \\
\hline $350-400$ & 375 & 7 & 551703 & 551207 & 1471 \\
\hline $400-450$ & 425 & 6 & 654010 & 653020 & 1539 \\
\hline $450-500$ & 475 & 3 & 760125 & 759172 & 1600 \\
\hline $500-550$ & 525 & 3 & 870682 & 869564 & 1658 \\
\hline $550-600$ & 575 & 2 & 983517 & 983341 & 1710 \\
\hline Total &.- & $\mathbf{5 1}$ & - & - & - \\
\hline Mean & $\mathbf{3 2 5}$ & $\mathbf{5 . 0}$ & $\mathbf{5 3 1 6 7 6}$ & $\mathbf{5 3 1 0 5 3}$ & 1352 \\
\hline
\end{tabular}

Table (5): The relationship between fecundity and the age (G) of the rabbitfish Siganus canaliculatus collected from the Arabian Gulf in Saudi Arabia.

\begin{tabular}{|c|c|c|c|c|c|}
\hline \multirow{2}{*}{$\begin{array}{c}\text { Age } \\
\text { (year) }\end{array}$} & \multirow{2}{*}{$\begin{array}{c}\text { No. of } \\
\text { fish }\end{array}$} & \multicolumn{2}{|c|}{ Absolute fecundity } & \multicolumn{2}{c|}{$\begin{array}{c}\text { Relative fecundity (Eggs / } \\
\text { year) }\end{array}$} \\
\cline { 3 - 6 } & & observed & calculated & observed & calculated \\
\hline 1 & $7 \cdot$ & 55173 & 55267 & 55173 & 55267 \\
\hline 2 & 15 & 179204 & 179563 & 89632 & 89781 \\
\hline 3 & $17-$ & 358725 & 357744 & 119575 & 119248 \\
\hline 4 & 9 & 581930 & 583402 & 145482 & 145850 \\
\hline 5 & $\cdot 3$ & 852376 & 852540 & 170475 & 170508 \\
\hline Total & 51 & - & - & - & - \\
\hline Mean & 10.2 & 405481 & 405703 & 945346 & - \\
\hline
\end{tabular}




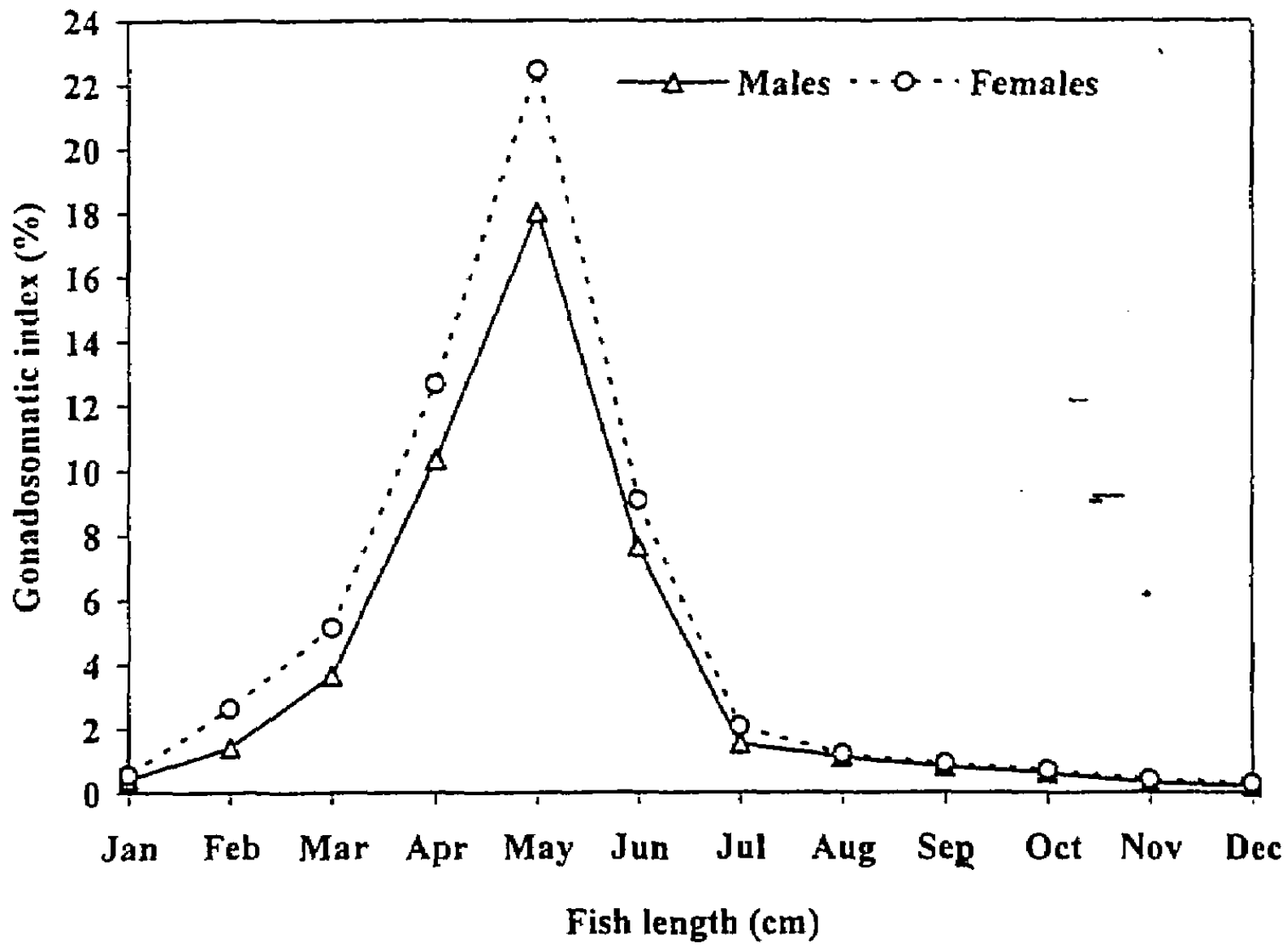

Fig. 1 Monthly variations of Gonadosomatic index (GSl, \%) for males and females of Siganus canaliculatus

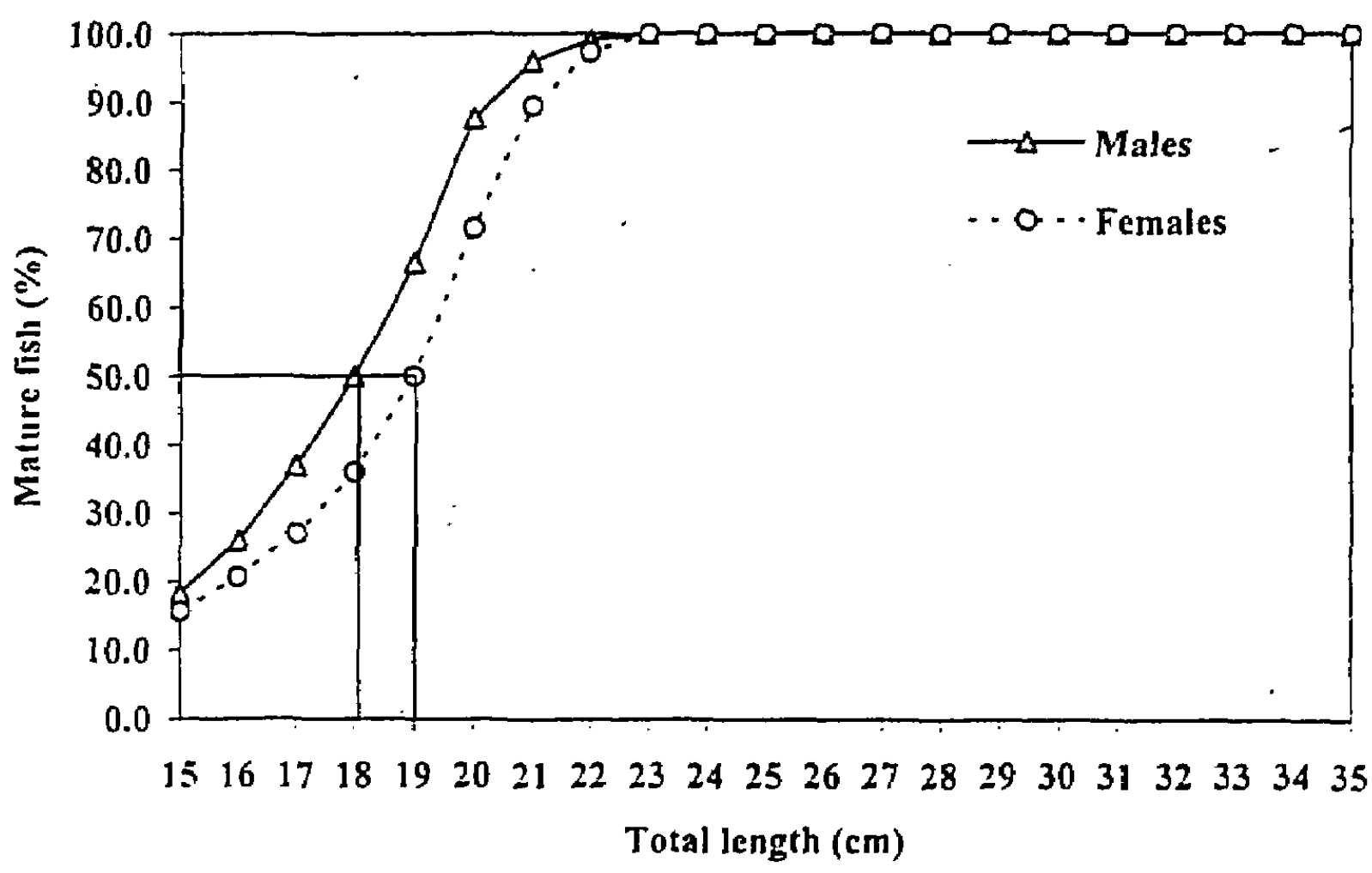

Fig. 2 The percentages of mature males and females of Siganus canaliculatus showing the length at first spawning ( $\mathrm{Lm}$ 50). 


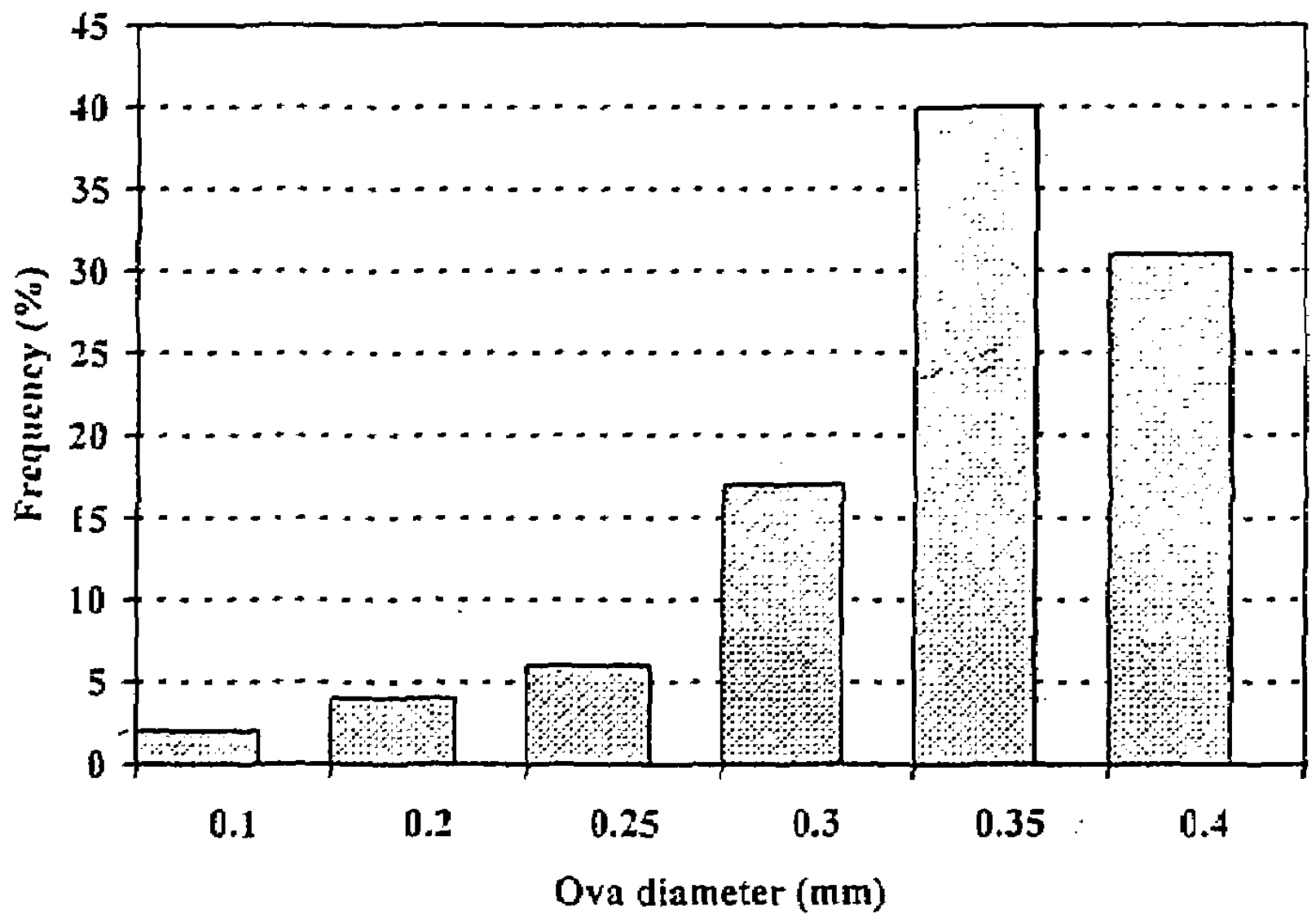

Fig. 3. Frequency distribution as a percentage (\%) of ova diameter in ripe ovaries of the rabbitfist Siganus canalicularus during the spawning senson.

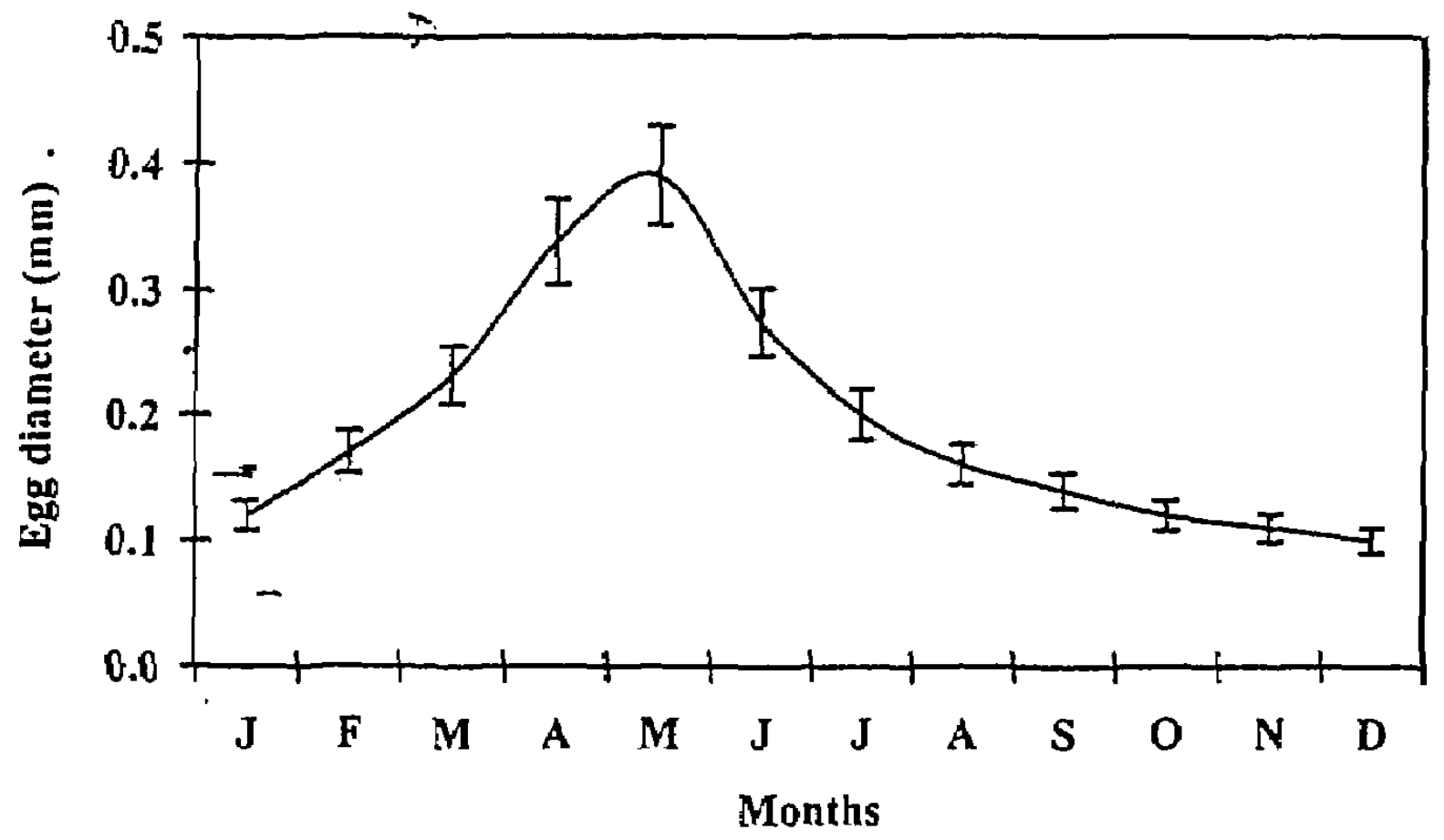

Fig. 4. The mean value of egg-diameter distributed monthly for the rabbitfish S. canaliculatus collected from the Arabian Gulf. 